BOLETIN LATINOAMERICANO Y DEL CARIBE DE PLANTAS MEDICINALES Y AROMÁTICAS

19 (4): 420 - 427 (2020)

๑ / ISSN 07177917 / www.blacpma.ms-editions.cl

Artículo Original | Original Article

\title{
Complete essential oils of Laurus nobilis inducing antinociceptive action by opioid mechanism in C-Reflex and spinal Wind-Up model in rat
}

\author{
[Aceites esenciales totales de Laurus nobilis inducen acción antinociceptiva mediante mecanismo opioide en el \\ modelo de Reflejo-C y Wind-Up espinal en ratas] \\ This article is written in tribute to Dr. Claudio Laurido (RIP) died on October 2017, \\ on the Third Anniversary of his Death \\ Carlos Valdés $^{1}$, Claudio Laurido ${ }^{1}$, Bernardo Morales ${ }^{1}$, Luisauris Jaimes ${ }^{1}$, ${\text { Raúl } \text { Vinet }^{2} \text { \& José L. Martínez }}^{3}$ \\ ${ }^{1}$ Facultad de Química y Biología, Universidad de Santiago de Chile \\ ${ }^{2}$ Facultad de Farmacia, Universidad de Valparaíso, Valparaíso, Chile \\ \& Centro Regional de Estudios en Alimentos Saludables (CREAS), Valparaíso, Chile \\ ${ }^{3}$ Vicerrectoría de Investigación, Desarrollo e Innovación, Universidad de Santiago de Chile \\ Contactos | Contacts: José L. MARTíNEZ - E-mail address: joseluis.martinez@ usach.cl
}

\begin{abstract}
The essential oil of Laurus nobilis L. was used to test their antinociceptive efficacy. It was applied intraperitoneally (i.p.) to rats subjected to a nociception test ( $\mathrm{C}$ reflex and spinal wind-up). The results showed that the essential oil applied at higher doses $(0.06 \mathrm{mg} / \mathrm{Kg})$ causes a complete abolition of the spinal wind-up, while the $\mathrm{C}$ reflex was unchanged, indicating a clear antinociceptive effect. At lower concentrations $(0.012 \mathrm{mg} / \mathrm{Kg})$, there was a lowering in the wind-up by $85 \%$ within ten minutes of the essential i.p. oil application. Interestingly, there was an effect of naloxone $(0.08 \mathrm{mg} / \mathrm{Kg}$ i.p.) When applied, a change occurs that almost entirely reversed the antinociception caused by the essential oil from Laurus nobilis. We conclude that there is a significant antinociceptive effect of the essential oil of Laurus nobilis subjected to electric nociception. In addition, it was observed that naloxone reversed the antinociceptive effect (windup) produced by Laurus nobilis.
\end{abstract}

Keywords: Laurus nobilis L.; Pain; C reflex; Spinal Wind-up

RESUMEN: El aceite esencial de Laurus nobilis L. se usó para probar su eficacia antinociceptiva. Se aplicó por vía intraperitoneal (i.p.) a ratas sometidas a una prueba de nocicepción (reflejo-C y wind-up espinal). Los resultados mostraron que el aceite esencial aplicado a dosis más altas $(0.06 \mathrm{mg} / \mathrm{Kg})$ abolió completamente el wind-up espinal, mientras que el reflejo-C no cambió, lo que indica un claro efecto antinociceptivo. A concentraciones más bajas $(0.012 \mathrm{mg} / \mathrm{Kg})$, hubo una disminución en el wind-up en un $85 \%$ dentro de los diez minutos del i.p. la aplicación del aceite esencial. Curiosamente, hubo un efecto de la naloxona $(0.08 \mathrm{mg} / \mathrm{Kg}$ i.p.) la cual revierte casi por completo la antinocicepción causada por el aceite esencial de Laurus nobilis. Concluimos que existe un efecto antinociceptivo significativo del aceite esencial de Laurus nobilis sometido a nocicepción eléctrica. Además, se observó que la naloxona revirtió el efecto antinociceptivo (windup) producido por Laurus nobilis.

Palabras clave: Laurus nobilis L.; Dolor; Reflejo-C; Wind-up espinal

Este artículo puede ser citado como / This article must be cited as: C Valdés, C Laurido, B Morales, L Jaimes, R Vinet, JL Martínez. 2020 Complete essential oils of Laurus nobilis inducing antinociception by opioid mechanism in C-Reflex and spinal Wind-Up model in rat. Bol Latinoam Caribe Plant Med Aromat 19 (4): 420 - 427. https://doi.org/10.37360/blacpma.20.19.4.29 


\section{INTRODUCTION}

The study of medicinal plants is becoming increasingly important, either from the popular knowledge (Barraza et al., 2014) and from the point of view of knowledge of the pharmacological properties of plants (de Almeida et al., 2003; Kumar, 2006; Wiart, 2007; Giogetti et al., 2011). Regarding Laurus nobilis, many studies have been conducted on other biological activities, among others, antioxidant protection (Kaurinovic et al., 2010; Ozcan et al., 2010; Al-Hashimi \& Mahmood, 2016; Akcan et al., 2017; Alejo-Armijo et al., 2017); insecticidal effect (Chahal et al., 2016; Jemaa et al., 2011; Salehi et al., 2014); antimicrobial effect (Fratianni et al., 2007; Ozcan et al., 2010; Fukuyama et al., 2011; El et al., 2014; Videla et al., 2016; Aliberti et al., 2016; Fidan et al., 2019); antibacterial effects (Moghtader \& Farahmand, 2013; Ouibrahim et al., 2013; Chahal et al., 2017; Mansour et al., 2018); antifungal effects (Marrufo et al., 2013; Rosello et al., 2015; Chahal et al., 2017); acaricidal effect (Macchioni et al., 2006); analgesic and anti-inflammatory activity (Sayyah et al., 2003; Esra et al., 2007; Kaileh et al., 2007; Alejo-Armijo et al., 2017; Maajida et al., 2019).

Numerous investigations have been carried out on the chemical composition of Laurus nobilis L. (Novak, 1985; Kilic et al., 2004; Fang et al., 2005; Dellacqua et al., 2006; Fukuyama et al., 2011; Patrakar et al., 2012; Alejo-Armijos et al., 2017; Caputo et al., 2017; Mansour et al., 2018; Fidan et al., 2019)

The definition of pain, according to the International Association for the Study of Pain states that: "Pain is an unpleasant sensory and emotional experience associated with actual or potential tissue damage or described by the patient as related to that injury" According to the above, pain is a sensory experience that should be expressed through language. If we wished to study pain in animals is a requirement that animals can talk. Therefore, $M$. Zimmerman (1986), adapted the definition of pain from the International Association for the Study of Pain, so it could be applied to animals: "An aversive sensory experience caused by actual or potential injury producing progressive motor and vegetative reactions triggers a behavior learned avoidance and may modify species-specific behaviors, including social".

\section{Nociception and animal testing}

Using the so-called argument from analogy, we can say that if a particular animal behavior is also present in humans, we can associate and say that apparently, the animals should feel the same and this justifies our experiments in pain studies, which in this case will call it nociception (Latin nocere, damage). The human babies have not language. This is an excellent reference to view their nociceptive reactions like those seen in animals. If you click baby foot with a sharp object, their reaction will be to immediately remove the affected limb. On the other hand, if you throw an object toward a person, it tends to avoid it, etc. Both reactions are observed in animals, the first called withdrawal reflex, and the ultimate, avoidance reflex. Both have the purpose of preventing nociception. Based on these behaviors (and other unnamed) we have formulated various tests nociception in animals such as Randall-Selitto test (Randall \& Selitto, 1957), Von Frey filaments (Pitcher et al., 1999), Thermal Gradient Test (Hargreaves et al., 1988), Electric Tail flick (Gardmark et al., 1998), nociception by stimulation of the trigeminal nerve (Laurido, 2011). They measure different aspects of nociception and are used in assays such as the test Randall-Selitto, used usually with animals with inflamed paw by injection, and normal paw, to evaluate drugs for analgesia; Tail Flick Apparatus for rapid and sensitive sampling analgesic effects, etc.

The main aim of this work was to test the anti-inflammatory effect of i.p. injections of Laurus nobilis challenged against the $\mathrm{C}$ reflex and wind-up paradigm.

\section{MATERIALS AND METHODS Plant material}

Leaves of Laurus nobilis were collected at the University of Santiago of Chile campus. In order to corroborate the plant material corresponds to Laurus, leaves and flowers were compared with the repository located at the Department of Botany and Herbarium of the Natural History National Museum, Santiago, Chile.

\section{Extraction of essential oil from Laurus}

Laurus nobilis leaves dried in darkness and at room temperature were subjected to hydrodistillation for 3 hours. Then the essential oil was stored at $4-5^{\circ} \mathrm{C}$. 


\section{Animals}

Thirty rats (Rattus norvegicus) of the SpragueDawley strain, normal male weighing between 250 and $350 \mathrm{~g}$ were used. The animals were obtained from the animal facilities of the Faculty of Medicine of the University of Chile and were maintained under a light-dark cycle of $12 / 12 \mathrm{~h}$., with food and water ad libitum. Animals were translated to our campus in aerated plastic boxes in an air conditioned car and then they were adapted for 24 hours after the travel before the experiments. All experiments were performed in accordance with the ethical guidelines of the International Association for the Study of Pain (Zimmermann, 1986) and the Committee on Bioethics of the University of Santiago of Chile.

The animals were divided into five experimental groups:

1. Six rats for control saline.

2. Six rats for injections of control Tween 80 .

3. Six rats for experiments with different concentrations of the essential oil of Laurus nobilis (high dose)

4. Six rats for experiments with different concentrations of the essential oil of Laurus nobilis (low dose)

5. Six rats for experiments using the essential oil of Laurus nobilis and naloxone.

\section{Reflex and Wind-up}

Spinal nociception was evaluated through nociceptive $\mathrm{C}$ reflex and wind-up. The $\mathrm{C}$ Reflex is a portion of an electromyographic recording evoked by electrical stimulation, which is the response of type $\mathrm{C}$ nerve fibers, corresponding to the range between 150 to $450 \mathrm{~ms}$ post-stimulus. This procedure is described briefly below. Once anesthetized the animals (injected i.p. urethane corresponding to a concentration of $1 \mathrm{~g} / \mathrm{kg}$ of body weight). Two platinum stimulating electrodes were inserted subdermally in the toes four and five in the right hind paw. Stimulation was performed with a Grass stimulator (S11) with pulses of $2 \mathrm{~ms}$ duration, usually 6-7 $\mathrm{mA}$ for normal animals and 3-5 $\mathrm{mA}$ for monoarthritic rats, and a frequency of $0.1 \mathrm{~Hz}$ for the $\mathrm{C}$ reflex, or $1.0 \mathrm{~Hz}$ for the wind-up. The stimulator is connected to a stimulus isolator unit (Grass SIU5) and then to a constant current unit (Grass CCU1) to prevent animal electrocution and regulate the applied current. The EMG activity was recorded in the ipsilateral biceps femoris, using two recording electrodes connected to an amplifier (DAM-80, WPI Instruments) and digitized by a PowerLab (2/20). Once digitized, the signal was displayed and recorded using Chart v4.2.3 software on a PC computer. The software rectified full wave signal and integrates the electromyographic recording between 150 and 450 $\mathrm{ms}$ post-stimulus. The data were stored for later analysis.

Once anesthetized, the animals with the stimulation and register electrodes was stimulated with supra-threshold current for $20 \mathrm{~min}$, to stabilize the preparation. Then, the stimulation threshold, which corresponds to the lowest current that is capable of generating a response is sought. The animals were stimulated for 15 minutes with twice the threshold $0.1 \mathrm{~Hz}$ to stabilize the response. Once stable C-reflex responses were obtained, the stimulus strength was lowered and the current required for threshold activation of the $\mathrm{C}$ reflex determined. Then we proceeded to record the stimuli at $0.1 \mathrm{~Hz}(\mathrm{C}$ reflex) and $1 \mathrm{~Hz}$ with intensity 2.0 times the threshold for the wind-up. In the case of $\mathrm{C}$ reflex, the values of registers 10 to 20 are averaged. In the case of wind-up, the slope of the first 7-8 records with increasing intensity was obtained. The results were expressed in arbitrary units.

\section{Statistical analysis}

Results were expressed as means \pm standard error of the mean (SEM). All the statistical analysis was done using one-way ANOVA, with a $p<0.01$ being significant. The calculations were done with the SigmaPlot, v12 for Windows (®2011, Systat Software, Inc.). In order to define the minimum number of rats, we made experiments increasing the number of animals and calculating for each $\mathrm{n}$, the standard deviation obtained and performing the statistical analysis in each case. The minimum number of animal that reaches a statistically significative result, then this result is considered. If the increase in the number of animals is greater than 5-6 without being statistically significant, then the experiment is not considered into the results.

\section{RESULTS}

We use the essential oil of Laurus nobilis L (Sayyah et al., 2003) extracted by hydrodistillation and tested with the $\mathrm{C}$ reflex and spinal wind-up. The essential oil was prepared with Tween 80 at $5 \% \mathrm{v} / \mathrm{v}$ applied in 
rats intraperitoneally at time zero. Results shows (Table No. 1) that at a high concentration of essential oil, wind-up is completely abolished, indicating a possible analgesic effect, whereas the $\mathrm{C}$ reflex remains unchanged.

Table No. 2 shows the application of a low concentration of the essential oil and the effect of naloxone. It can be seen that the application of 0.012 $\mathrm{mg} / \mathrm{Kg}$ of essential oil at time zero, produces a lowering in the wind-up by $85 \%$ at time 30 minutes, compared to the control. It is also interesting to note that there was an effect of naloxone $(0.08 \mathrm{mg} / \mathrm{Kg}$, i.p.) (Sayyah et al., 2003; You et al., 2003), which tends to reverse the analgesic effects of the essential oil in the wind-up. This would indicate a possible effect of opioid receptor level, the result described by the first time.

\section{DISCUSSION}

Our group has been dedicated to studying pain through different methods, being Dr. Claudio Laurido who directed these works (Laurido et al., 2001; Laurido, 2011; Laurido et al., 2012; Laurido et al., 2013; Valdes et al., 2015; Bustos et al., 2016; Valdes et al., 2018). This article contains the last results by the obtained one.

\begin{tabular}{|c|c|c|c|c|}
\hline \multicolumn{5}{|c|}{ Table No. 1 } \\
\hline Time (min) & \multicolumn{2}{|c|}{ Control } & Laurus (0.06 mg/Kg) \\
\hline & C Reflex & Wind-up & C reflex & Wind-up \\
\hline 0 & $4.6 \pm 0.02$ & $5.5 \pm 0.01$ & $0.34 \pm 0.01$ & $5.5 \pm 0.01$ \\
\hline 10 & $4.8 \pm 0.01$ & $5.3 \pm 0.02$ & $0.30 \pm 0.02$ & 0 \\
\hline 20 & $4.7 \pm 0.03$ & $5.4 \pm 0.10$ & $0.32 \pm 0.01$ & 0 \\
\hline
\end{tabular}

Table No. 1

The table shows the effect on the $\mathrm{C}$ reflex and wind-up of the application of a high dose of Laurus essential oil. Results are expressed as mean $\pm \mathrm{SE}, \mathrm{n}=6$.

\begin{tabular}{|c|c|c|c|c|c|}
\hline \multicolumn{7}{|c|}{ Table No. 2 } \\
\hline \multirow{2}{*}{ Time (min) } & \multicolumn{2}{|c|}{ Control } & \multicolumn{2}{c|}{ Laurus $(\mathbf{0 . 0 1 2} \mathbf{~ m g} / \mathbf{K g})$} & $\begin{array}{c}\text { Naloxone } \\
(\mathrm{mg} / \mathrm{Kg})\end{array}$ \\
\hline & C Reflex & Wind-up & C Reflex & Wind-up & \\
\hline $\mathbf{0}$ & $4.7 \pm \mathbf{0 . 0 1}$ & $\mathbf{5 . 5} \pm \mathbf{0 . 1 0}$ & $\mathbf{4 . 8 7} \pm \mathbf{0 . 0 1 0}$ & $\mathbf{5 . 6} \pm \mathbf{0 . 1 2}$ & \\
\hline 10 & $4.8 \pm \mathbf{0 . 0 1}$ & $\mathbf{5 . 3} \pm \mathbf{0 . 0 1}$ & $\mathbf{4 . 7 1} \pm \mathbf{0 . 0 2 0}$ & $\mathbf{2 . 2} \pm \mathbf{0 . 1} *$ & \\
\hline 30 & $4.6 \pm \mathbf{0 . 0 1}$ & $\mathbf{5 . 4} \pm \mathbf{0 . 0 2}$ & $\mathbf{4 . 9 4} \pm \mathbf{0 . 0 1 5}$ & $\mathbf{0 . 8 1} \pm \mathbf{0 . 1 2} *$ & $\mathbf{0 . 0 8}$ \\
\hline $\mathbf{5 0}$ & $4.7 \pm \mathbf{0 . 0 2}$ & $\mathbf{5 . 3} \pm \mathbf{0 . 1 0}$ & $\mathbf{5 . 2 2} \pm \mathbf{0 . 0 1 2}$ & $\mathbf{5 . 6 2} \pm \mathbf{0 . 0 2}$ & \\
\hline 60 & $4.7 \pm \mathbf{0 . 0 2}$ & $\mathbf{5 . 5} \pm \mathbf{0 . 1 2}$ & $\mathbf{5 . 0 3} \pm \mathbf{0 . 0 2 0}$ & $\mathbf{7 . 3 6} \pm \mathbf{0 . 8}$ & \\
\hline
\end{tabular}

Table No. 2

The table shows the application of a lower concentration of the Laurus essential oil and the effect of naloxone. Results are expressed as mean $\pm \mathrm{SE}, *=p<0.01$ indicate the values are statistically different from the wind-up control, $n=6$

In this study, the results of the antiinflammation effect of the essential oil of Laurus nobilis occurred in normal rats are shown. There is only one previous work in which the effect of Laurus nobilis in the tail flick test and the formalin test (Sayyah et al., 2003) was studied. A significant analgesic effect of the extract, which came to completely suppress the wind-up cord (Table No. 1) was found. NMDA receptors play an important role in the initiation and maintenance of chronic pain, and so the study of this type of pain in animal models of chronic pain (monoarthritis, for example) could give interesting results. Another effect found what the possible existence of actions of the essential oil of Laurus nobilis on spinal opioid receptors because when naloxone was applied, an increase in the windup occurs; reaching values approximate those of the controls (Table No. 2). 
In attempting to establish a correlation between the observed effects and properties of some components of Laurus nobilis essential oil can be seen in Table No. 3. Components 1,8-cineole, alphaterpinyl acetate, and sabinene are described as antagonists TRPA1 receptors, anti-inflammatory, and analgesic, and anti-inflammatory, respectively. Eugenol, as a modulator of the opioid system and the glutamatergic receptors (AMPA and kainate) and inhibition of TNF- $\alpha$. However, when analyzing the percentage of these compounds present in the essential oil of Laurus nobilis and pretend to correlate with antinociception, it becomes very difficult. This is because there may be synergistic or antagonistic effects among the remaining components (81 compounds) of the complete essential oil of Laurus nobilis. There are other extraction methods different from hydrodistillation, by ultrasound application (Muñiz-Marquez et al., 2013), or enzyme-assisted (Boulila et al., 2015), but whether these extractions can make differences on the observed antinociception, remains to be elucidated.

\begin{tabular}{|c|c|c|c|}
\hline \multicolumn{3}{|c|}{ Table No. 3 } \\
\hline Sample \% & $\begin{array}{c}\text { Compound } \\
\text { Isolated }\end{array}$ & Pharmacological action & Bibliographic reference \\
\hline $\mathbf{5 8 . 5 9}$ & $\begin{array}{c}\text { 1,8-cineole } \\
\text { Alpha terpinyl } \\
\text { acetate }\end{array}$ & $\begin{array}{c}\text { TRPM8 receptor antagonist } \\
\text { Antimicrobial and anti- } \\
\text { inflammatory. Possible peripheral } \\
\text { analgesic. }\end{array}$ & $\begin{array}{c}\text { (Takaishi } \text { et al., 2012) } \\
\text { (Peana } \text { et al., 1999) }\end{array}$ \\
\hline 3.32 & Sabinene & Anti-inflammatory & (Valente et al., 2013) \\
\hline $\mathbf{0 . 1 6}$ & Eugenol & $\begin{array}{c}\text { Modulator of the opioid system } \\
\text { and glutamatergic receptors } \\
\text { (Kainate and AMPA), TNF-a } \\
\text { inhibitor. }\end{array}$ & (Bo et al., 2013) \\
\hline
\end{tabular}

Table No. 3

Some compounds isolated from the essential oil of Laurus presenting pharmacological actions relevant to this work. (Taken from Sayyah et al., 2003)

\section{CONCLUSION}

We conclude that the essential oil of Laurus nobilis has a significant analgesic activity in the $\mathrm{C}$ reflex model. The pro-nociceptive effect of naloxone was also observed, possibly due to the modulatory effect of the spinal opioid system that presents the essential oil of Laurus nobilis. Whether the essential oil presents an anti-inflammatory activity, remains to be elucidated through the use of animal models of chronic pain.

\section{ACKNOWLEDGMENT}

The authors are grateful to Universidad de Santiago de Chile, project DICYT number 021343LF of CL and partially project DICYT number $021643 \mathrm{MS}$ of JLM.

\section{REFERENCES}

Akcan T, Estevez M, Serdaroglu M. 2017. Antioxidant protection of cocked meatballs during frozen storage by whey protein edible films with phytochemicals from Laurus nobilis L and Salvia officinalis. LWT - Food Science Technol 77: 323 - 331. https://doi.org/10.1016/j.lwt.2016.11.051

Alejo-Armiojo A, Altarejos J, Salido S. 2017. Phytochemicals and biological activities of laurel tree (Laurus nobilis). Nat Prod Commun 12: 743-757. https://doi.org/10.1177/1934578x1701200519

Al-Hashimi AG, Mahmood SA. 2016. The nutritional value and antioxidant activity of bay leaves (Laurus nobilis L.). Basrah J Vet Res 15: 246 - 259. https://doi.org/10.33762/bvetr.2016.124310

Aliberti L, Caputo L, de Feo V, de Martino L, Nazzaro F, Souza LF. 2016. Composition and in vitro antimicrobial, cytotoxic and central nervous system activities of the essential oils of Citrus medica L. cv 'Liscia' and $C$. 
medica cv 'Rugosa' cultivated in southern Italy. Molecules 21: 1244.

https://doi.org/10.3390/molecules21091244

Barraza F, Calvo C, Silva M, Vinet R, Laurido C, Barrera E, Meza I, Vargas-Rueda S, Martínez JL. 2014. Traditional ethnobotanical knowledge and use of medicinal plants in a rural area of the metropolitan region of Chile: descriptive study. Bol Latinoam Caribe Plant Med Aromat 13: 366 - 374.

Bó WD, Luiz AP, Martins DF, Mazzardo-Martins L, Santos ARS. 2013. Eugenol reduces acute pain in mice by modulating the glutamatergic and tumor necrosis factor alpha (TNF- $\alpha$ ) pathways. Fund Clin Pharmacol 27: 517 - 525. https://doi.org/10.1111/j.1472-8206.2012.01052.x

Boulila A, Hassen I, Haouari L, Mejri F, Amor IB, Casabianca H, Hosni K. 2015. Enzyme-assisted extraction of bioactive compounds from bay leaves (Laurus nobilis L.). Ind Crops Prod 74: 485 - 497. https://doi.org/10.1016/j.indcrop.2015.05.050

Bozan B, Karakaplan U. 2007. Antioxidants from laurel (Laurus nobilis L.) berries: influences of extraction procedure on yield and antioxidant activity of extract. Acta Alim 36: 321 - 328. https://doi.org/10.1556/aalim.36.2007.3.4

Bustos G, Valdés C, Martinez JL, Laurido C. 2016. Digitalization of a pressure-transducer based plethysmograph through a PowerLab Equipment for recording rat paw volumen. Pak Vet J 36: 366 - 368.

Caputo L, Nazzaro F, Souza LF, Aliberti L, de Martino L, Fratiani F, Coppola R, de Feo V. 2017. Laurus nobilis: composition of essential oil and its biological activities. Molecules 22: 930. https://doi.org/10.3390/molecules22060930

Chahal KK, Bansal R, Kaur R. 2016. Chemistry and insecticidal potential of bay leaf essential oil againnst stored grain pest of wheat. J Appl Natural Sci 8: 2049 - 2054. https://doi.org/10.31018/jans.v8i4.1085

Chahal KK, Kaur M, Bhardwaj U, Singla N, Kaur A. 2017. A review on chemistry and biological activities of Laurus nobilis L. essential oil. J Pharmacogn Phytochem 6: 1153 - 1161.

De Almeida RN, Motta SC, Leite JR. 2003. Óleos essenciais com propriedades anticonvulsivantes. Bol Latinoam Caribe Plant Med Aromat 2: 1 - 11.

Dellacqua S. Viola G, Giorgetti M, Loi MC, Innocenti G. 2006. Two new sesquiterpene lactones from the leaves of Laurus nobilis. Chem Pharm Bull 54: 1187 - 1189. https://doi.org/10.1248/cpb.54.1187

El SN, Karagozlu N, Karakaya S, Sahin S. 2014. Antioxidant and antimicrobial activities of essential oils extracted from Laurus Nobilis L. leaves by using solvent-free microwave and hydrodistillation. Food Nut Sci 5: 97 106. https://doi.org/10.4236/fns.2014.52013

Esra K, Iikay O, Erdem Y, 2007. Evaluation of some plants used in Turkish folk medicine for their antiinflammatory and antinociceptive activities. Pharmac Biol 45: 547 - 555. https://doi.org/10.1080/13880200701498895

Fang F, Sang S, Chen KY, Gosslau A, Ho CT, Rosen RT. 2005. Isolation and identification of cytotoxic compound from Bay leaf (Laurus nobilis). Food Chem 93: 497 - 501. https://doi.org/10.1016/j.foodchem.2004.10.029

Fidan H, Stefanova G, Kostova I, Stankov S, Damyanova S, Stoyanova A, Zheljazkov VD. 2019. Chemical composition and antimicrobial activity of Laurus nobilis L. essential oils from Bulgaria. Molecules 24: 804. https://doi.org/10.3390/molecules24040804

Fratianni F, Sada A, Masucci A, Cipriano L, Nazzaro F. 2007. Biochemical characteristics, antimicrobial and mutagenic activity ion organically and conventionally produced Malus domestica, Annurca. Open Food Sci J 1: 10 - 16. https://doi.org/10.2174/1874256400701010010

Fukuyama N, Ino C, Suzuki Y, Kobayashi N, Hamamoto H, Sekimizu K, Orihara Y. 2011. Antimicrobial sesquiterpenoids from Laurus nobilis L. Nat Prod Res 25: 1295 - 1303.

https://doi.org/10.1080/14786419.2010.502532

Gårdmark M, Höglund AU, Hammarlund-Udenaes M. 1998. Aspects on tail-flick, hot-plate and electrical stimulation tests for morphine antinociception. Pharmacol Toxicol 83: 252 - 258. https://doi.org/10.1111/j.1600-0773.1998.tb01478.x

Giorgetti M, Rossi L, Rodrigues E. 2011. Brazilian plants with possible action on the central nervous system - a study of historical sources from the 16th to 19th century. Braz J Pharmacogn 21: 537 - 555. https://doi.org/10.1590/s0102-695x2011005000044

Boletín Latinoamericano y del Caribe de Plantas Medicinales y Aromáticas/425 
Hargreaves K, Dubner R, Brown F, Flores C Joris J. 1988. A new and sensitive method for measuring thermal nociception in cutaneous hyperalgesia. Pain 32: 77 - 88. https://doi.org/10.1016/0304-3959(88)90026-7

Jemaa MB, Tersim JN, Khouja. 2011. Composition and repellent efficacy of essential oil from Laurus nobilis against adults of the cigarette beetle Lasioderma serricorne (Coleoptera: Anobiidae). Tunisian J Plant Protection 6: 29 - 42. https://doi.org/10.17660/actahortic.2013.997.20

Kaileh M, Berghe W, Boone E, Essawi T, Haegeman G. 2007. Screening of indigenous Palestinian medicinal plants for potential anti-inflammatory and cytotoxic activity. J Ethnopharmacol 113: 510 - 516. https://doi.org/10.1016/j.jep.2007.07.008

Kaurinovic B, Popovic M, Vlaisavljevic S. 2010. In vitro and in vivo effects of Laurus nobilis L. leaf extracts. Molecules 15: 3378 - 3390. https://doi.org/10.3390/molecules15053378

Kilic A, Hafizoglu H, Kollmannsberger H, Nitz S. 2004. Volatile constituents and key odorants in leaves, buds, flowers and fruits of Laurus nobilis L. J Agric Food Chem 52: 1601 - 1606. https://doi.org/10.1021/jf0306237

Kumar V. 2006. Potential medicinal plants for CNS disorders: an overview. Phytother Res 20: 1023 - 1035. https://doi.org/10.1002/ptr.1970

Laurido C, Pelissier T, Perez H, Flores F, Hernandez A. 2001. Effect of ketamine on spinal cord nociceptive transmission in normal and monoarthritic rats. Neuroreport 12: 1551 - 1554. https://doi.org/10.1097/00001756-200106130-00008

Laurido C. 2011. Reflejo C evocado en el músculo digástrico: Un nuevo método para evaluar actividad wind-up trigeminal aplicable a principios activos de plantas medicinales. Bol Latinoam Caribe Plant Med Aromat 10: 500 - 506.

Laurido C, Hernández A, Pelissier T, Constandil L. 2012. Antinociceptive effect of rat d-serine racemase inhibitors, 1-serine-o-sulfate, and l-erythro-3-hydroxyaspartate in an arthritic pain model. Scient World J Volume 2012, Article ID 279147, 5 pages. https://doi.org/10.1100/2012/279147

Laurido C, Martínez JL, Morales F. 2013. Electrophysiological study of the antinociception produced by the coapplication of ( \pm -CPP and propentofylline in monoarthritic rats. ISRN Pain Article ID 315626, 5 pages. https://doi.org/10.1155/2013/315626

Maajida AM, Geetha RV, Lakshmi T. 2019. Evaluation of anti-inflammatory action of Laurus nobilis an in vitro study. Int J Res Pharm Sci 10: 1209 - 1213. https://doi.org/10.26452/ijrps.v10i2.408

Macchioni F, Perrucci S, Cioni P, Morelli I, Castilho P, Cecchi P. 2006. Composition and acaricidal activity of Laurus novocanariensis and Laurus nobilis essential oils against Psoroptes cuniculi. J Essent Oil Res 18: 111 - 114. https://doi.org/10.1080/10412905.2006.9699403

Mansour O, Darwish M, Ismail G, Douba ZA, Ismaeel A, Eldair KS. 2018. Review study on the physiological properties and chemical composition of the Laurus nobilis. Pharmaceut Chem J 5: 225 - 231.

Marrufo T, Nazzaro F, Mancini E, Fratianni F, Coppola R, de Martino L, Bela Agostinho A, de Feo V. 2013. Chemical composition and biological activity of the essential oil from leaves of Moringa oleifera Lam. cultivated in Mozambique. Molecules 18: 10989 - 11000. https://doi.org/10.3390/molecules180910989

Moghtader M, Farahmand A. 2013. Evaluation of the antibacterial effects of essential oil from the leaves of Laurus nobilis L in Kerman province. J Microbiol Antimicrobials 5: 13 - 17. https://doi.org/10.5897/jma2012.0233

Muñiz-Márquez DB, Martínez-Avila GC, Wong-Paz JE, Belmares-Cerda R, Rodríguez-Herrera R, Aguilar CN. 2013. Ultrasound-assisted extraction of phenolic compounds fron Laurus nobilis L. and their antioxidant activity. Ultrasonics Sonochemistry 20: 1149 - 1154. https://doi.org/10.1016/j.ultsonch.2013.02.008

Novak M. 1985. A monoterpene alcohol from Laurus nobilis. Phytochemistry 24: 858. https://doi.org/10.1016/s0031-9422(00)84909-2

Ouibrahim A, Tlili-Ait-kaki Y, Bennadja S, Amrouni S, Djahoudi AG, Djebarl MR. 2013. Evaluation of antibacterial activity if Laurus nobilis L., Rosmarinus officinalis L. and Ocimum basilicum L. from Northeast of Algeria. Afr J Microbiol Res 7: 4968 - 4973. https://doi.org/10.5897/ajmr2012.2390

Ozcan B, Esen M, Sangun MK, Coleri A, Caliskan M, 2010. Effective antibacterial and antioxidant properties of methanolic extract of Laurus nobilis seed oil. J Environment Biol 31: 637 - 641. 
Peana AT, Moretti MD, Juliano C. 1999. Chemical composition and antimicrobial action of the essential oils of Salvia desoleana and S. sclarea. Planta Med 65: 752 - 754. https://doi.org/10.1055/s-2006-960857

Patrakar R, Mansuriya M, Patil P. 2012. Phytochemical and pharmacological review on Laurus nobilis. Int J Pharm Chem Sci 1: 595 - 602.

Pitcher GM, Ritchie J, Henry JL. 1999. Paw withdrawal threshold in the von Frey hair test is influenced by the surface on which the rat stands. J Neurosci Methods 87: 185 - 193. https://doi.org/10.1016/s0165-0270(99)00004-7

Randall LO, Selitto JJ. 1957. A method for measurement of analgesic activity on inflamed tissue. Arch Int Pharmacodyn Ther 111: 409 - 419.

Rosello J, Sampere F, Sans-Berzosa I, Amparo CA, Santamarina JMP. 2015. Antifungal activity and potential use of essential oils against Fusarium culmorum and Fusarium verticillioides. J Essent Oil Bearing Plant 18: 359 - 367. https://doi.org/10.1080/0972060x.2015.1010601

Salehi T, Karimi J, Hasanshahi G, Askarianzadeh A, Abbasipour H. 2014. The effect of essential oils from Laurus nobilis and Myrtus commonis on the adults of Mediterranean flour moth, Ephestia kuehniella Zeller (Lep: Pyralidae). J Essent Oil Bearing Plants 17: 553 - 561. https://doi.org/10.1080/0972060x.2014.935059

Sayyah M, Saroukhani G, Peirovi A, Kamalinejad M. 2003. Analgesic and anti-inflammatory activity of the leaf essential oil of Laurus nobilis Linn. Phytother Res 17: 733 - 736. https://doi.org/10.1002/ptr.1197

Takaishi M, Fujita F, Uchida K, Yamamoto S, Sawada M, Hatai C, Shimizu M, Tominaga M. 2012. 1,8-cineole, a TRPM8 agonist, is a novel natural antagonist of human TRPA1. Mol Pain 8: 86. https://doi.org/10.1186/1744-8069-8-86

Valdes C, Martinez JL, Laurido C. 2015. Design and testing of a device for drug infusion and collection of continuous or batch cerebrospinal fluid (CSF) in rats: pharmacokinetic study of CSF fluorescein injected intravenously and infused minocycline. Pak Vet J 35: 147 - 150.

Valdes C, Bustos G, Martinez JL, Laurido C. 2018. Antinociceptive antibiotics-loaded into solid lipid nanoparticles of prolonged release: Measuring pharmacological efficiency and time span on chronic monoarthritis rats. Plos One 13: e0187473. https://doi.org/10.1371/journal.pone.0187473

Valente J, Zuzarte M, Gonçalves MJ, Lopes MC, Cavaleiro C, Salgueiro L, Cruz MT. 2013. Antifungal, antioxidant and anti-inflammatory activities of Oenanthe crocata L. essential oil. Food Chem Toxicol 62: 349 - 354. https://doi.org/10.1016/j.fct.2013.08.083

Videla J, Martins D, Monteiro-Silva F, González-Aguilar G, de Almeida JMMM, Saraiva C. 2016. Antimicrobial effect of essential oils of Laurus nobilis L and Rosmarinus officinalis L on shelf-life of minced "Maronesa" beef stored under different packaging contitions. Food Packag Shelf Life 8: 71 - 80. https://doi.org/10.1016/j.fpsl.2016.04.002

Wiart C. 2007. Plant affecting the central nervous system. In Ethnopharmacology of medicinal plant: Asia and the Pacific. Springer, New York, USA.

You HJ, Morch CD, Chen J, Arendt-Nielsen L. 2003. Simultaneous recording of widp-up of paired spinal dorsal horn nociceptive neuron and nociceptive flexion reflex in rats. Brain Res 960: 235 - 245. https://doi.org/10.1016/s0006-8993(02)03895-7

Zimmermann M. 1986. Behavioural investigations of pain in animals. In Duncan IJH, Molony V (eds), Assessing pain in farm animals. Office for Official Publications of the European Communities, Brussels, Belgium. 